\title{
STAKEHOLDERS' PRACTICES: A CHALLENGE TO EARTHQUAKE RISK MITIGATION DECISIONS
}

\author{
Temitope EGBELAKIN ${ }^{\text {a, }}$ *, Suzanne WILKINSON ${ }^{\text {b }}$, Regan POTANGAROA ${ }^{\mathrm{c}}$, \\ James ROTIMI d \\ a School of Engineering and Advanced Technology, Massey University, Private Bag 102 904, \\ North Shore City 0745, Auckland, New Zealand \\ ${ }^{b}$ Department of Civil and Environmental Engineering, The University of Auckland, Auckland, \\ New Zealand \\ ${ }^{c}$ School of Architecture, Unitec Institute of Technology, Auckland, New Zealand \\ ${ }^{d}$ School of Engineering, Auckland University of Technology, Auckland, New Zealand
}

Received 13 August 2013; accepted 12 November 2014

\begin{abstract}
Enhancing building owners' earthquake risk preparedness has been a major challenge in many seismically active regions. Many property owners are found unwilling to adopt adequate risk mitigation measures in their earthquake-prone buildings, despite the availability of various technical design solutions and the enactment of intervening legislative frameworks necessary to facilitate successful earthquake risk preparedness. This paper examined the rationale behind building owners' unwillingness to adopt adequate mitigation measures with a view to improve current stakeholders' practices in earthquake risk mitigation. Using a mixed-method approach, comprising both qualitative and quantitative methods, an examination of the decision-making process and different stakeholders involved in earthquake risk mitigation and the property market, provided insights into the causal agents and stakeholder practices that pose challenges to property owners' mitigation decisions. Stakeholder practices acting as impediments revealed are property valuation assessment of retrofitted and non-retrofitted EPBs, lack of demand for improved performance in older buildings, high earthquake insurance policy premiums and deductibles, and lack of a risk assessment information system. An indepth understanding of these challenges highlights the need for a holistic approach that should incorporate market-based incentives necessary for successful earthquake preparedness by building owners, and for designing effective strategies for improving earthquake risk mitigation.
\end{abstract}

KEYWORDS: Stakeholders; Property market; Seismic mitigation decision; Earthquake-prone buildings (EPBs); Property owners

\section{INTRODUCTION}

Earthquake risk preparedness is essential to reduce losses associated with seismic disasters. Earthquake disaster losses could be minimised by implementing appropriate risk mitigation decisions regarding seismic retrofitting of earthquake-prone buildings (EPBs) (Dowrick 2003). EPBs are considered to be buildings that will have their ultimate structural performance capacity exceeded in a moderate earthquake, and would probably collapse causing injury or death to persons within the buildings (Department of Building and Housing 2004). EPB is a standard term used to describe such category of buildings

\footnotetext{
* Corresponding author. E-mail: T.Egbelakin@massey.ac.nz
}

in New Zealand. EPBs with insufficient seismic capacity contribute to the susceptibility of the built environment to earthquake hazard and are the key contributors to earthquake losses (Spence 2007). These buildings are constructed, owned and inhabited by owners who make a range of decisions and choices that shape their level of vulnerability. Some owners make decisions to minimise their exposure to risks by adopting mitigation measures, some choose to ignore the risks, while others accept the risk without undertaking any protective measures (Burton et al. 2002). The 2011 Canterbury earthquakes in New Zealand revealed that property owners adopted risk 
reduction measures in varying degrees without adequate consideration of their vulnerability to seismic hazard (Egbelakin et al. 2011b; Egbelakin et al. 2013).

Seismic rehabilitation of EPBs by property owners lags behind advances in scientific and engineering understanding, because little attention has focused on understanding and developing strategies to overcome the barriers associated with implementing seismic retrofitting (Hopkins et al. 2006). Previous studies in the social, economic and decision sciences have sought to address property owners' uptake of mitigation measures from different perspectives such as socio-behavioural, regulatory, economic, cultural, and institutional, but these efforts have not resulted in satisfactory success (Tierney et al. 2005; Smith 2009; Egbelakin 2013). Despite this volume of studies, building owners are still found to be reluctant to adopt adequate mitigation measures (Egbelakin et al. $2011 b)$. It is possible that the practices and recommendations from other stakeholders involved in the decision-making process could contribute to property owners' unwillingness to adopt adequate mitigation measures in their EPBs.

The conceptualisation of seismic risk mitigation decisions focused mainly on individual building owners as highlighted by previous research (Solberg et al. 2010; Arlikatti et al. 2007; Egbelakin et al. 2011a). The impacts of the opinions and recommendations from other stakeholders in property owners' mitigation decisions have been under-researched (Egbelakin 2013). For instance, opinions and recommendations from these stakeholders may differ on the level of seismic performance standard proposed, type of mitigation measures and technical solutions recommended for particular buildings. Besides, discrepancies that exist between the stakeholders' opinions and recommendations could affect building owners' mitigation decisions (Pidgeon et al. 2003). The current research examines the critical barriers to successful earthquake preparedness by investigating how practices of the different stakeholders involved in seismic risk mitigation decisions could act as impediments to building owners' adoption of mitigation measures, and seeks ways to improve such practices. This way, the study contributes to the discourse on methods and strategies that could improve such practices, and consequently improve the likelihood that building owners will adopt adequate risk mitigation measures when retrofitting their EPBs.

\subsection{Challenges associated with earthquake risk mitigation decisions}

Earthquake risk mitigation decision-making refers to choices made by people to reduce losses related to earthquake disasters. Implementing earthquake risk mitigation measures involves addressing the uncertainties associated with EPBs and the problems related to the multi-disciplined stakeholders involved in the decision-making process (Bostrom et al. 2006). The diversity of stakeholders (often multi-discipline, with different backgrounds and motivations) involved in risk mitigation decisions and disaster management, pose challenges to property owners when they assess recommendations from these diverse stakeholders (Dowrick 2003). The diversity of stakeholder groups and different levels of their involvement in final decisionmaking could lead to biased inputs (McElroy, Mills 2008). The final decision to adopt earthquake risk mitigation mechanisms could be influenced by compliance requirements to building regulations, profit-making, heritage conservation and the need to ensure safety (Egbelakin, Wilkinson 2008). Moreover, the different perceptions of earthquake risk amongst the stakeholders could contribute to disparate opinions regarding the level of acceptable risks when making seismic retrofit decisions (Slovic 2001).

Seismic risk mitigation decisions involve the evaluation and selection of an appropriate course of action to reduce losses from earthquake disasters. Seismic retrofitting of existing EPBs is rarely the sole consideration during a building rehabilitation programme, but instead sits alongside competing factors such as mechanical upgrades and maintenance, increasing rental value and other risks (including fire and flood) related to a property. The Earthquake Engineering Research Institute report (1998) suggests that no two buildings go through precisely the same decision-making process, after examining many different seismic mitigation decisions and conducting interviews with a range of building owners. The context in which each decision is made is also significant, as several tradeoffs are considered during the process. Earthquake mitigation decisions are further influenced by the interaction of factors such as psychological, social, economic, cultural, institutional, political and processes within the community which renders seismic risk mitigation challenging and complex (Egbelakin et al. 2011b; Solberg et al. 2010). Further, other factors that include property ownership types, buildings' structural characteristics and the cost of retrofitting that become apparent during 
the decision-making process could also influence the outcome of a final mitigation decision (Egbelakin, Wilkinson 2010).

Changes in property market conditions related to building sale and lease transactions could affect owners' seismic mitigation decisions. According to Stevens and Wheeler (2008), 65\% of potential EPB owners in Wellington, New Zealand, did not respond to notices issued to them by the city council, during initial evaluation procedure for earthquake risk mitigation within the region. However, prompt responses were received from owners whose properties were on sale, suggesting that increased awareness of seismic risk in the property market could potentially affect property business transactions regarding sales value and net income streams of potential EPBs. Studies on earthquake risks and property market prices have found correlations between property value, seismic risks information and communication methods, governmentinitiated policies and programmes, house prices and owners' attitudes towards the implementation of mitigation measures (Onder et al. 2004; Willis, Asgary 1997). However, the property market is noted for its multi-disciplinary stakeholder issues and abbreviated flows of seismic risk information, and thus is far from efficient in promoting seismic retrofit implementation (Beck et al. 2002). It is possible that the current stakeholder practices or activities in the property market could influence seismic retrofitting of EPBs. The next section provides an overview of the stakeholders involved in seismic mitigation and property market investment decisions, in order to provide insights into their roles in earthquake risk mitigation.

\subsection{Stakeholders involved in seismic risk mitigation and property market investment decisions}

Seismic retrofit implementation involves a decision to reduce the built environment's earthquake vulnerability, while a property investment decision ensures that investors achieve satisfactory return on their investments in the market place. Investors' return could be in form of income flow, capital gain or a combination of both (Adair et al. 1994). Arguably, when an EPB is concerned, the same stakeholders are involved in both decisionmaking processes. For the purpose of this study, stakeholders involved in earthquake risk mitigation and property investment decisions include owners of buildings and businesses, government/ regulatory bodies (local councils, industry groups), property investors and developers, property valuers, real estate agents, managers of financial and insurance institutions, tenants/users and property and hazard-related professionals such as engineers and architects (Egbelakin 2013).

These stakeholders operate within the private and public sectors, and in operative environments such as built, regulatory, investment and external environments (see Fig. 1), and could have a varying influence on a building owner's risk mitigation decision.

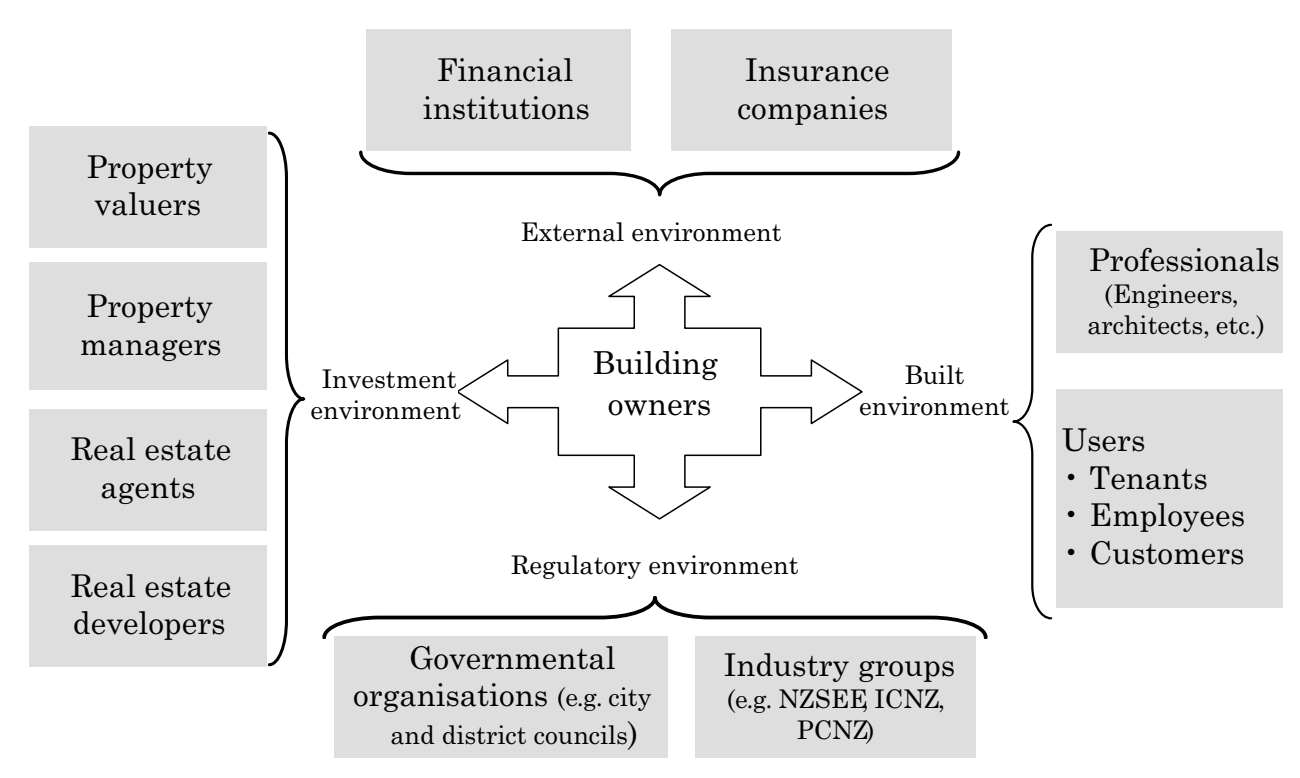

Fig. 1. Stakeholders involved in property market investment and seismic risk mitigation decisions

Notes: Zealand Society for Earthquake Engineering (NZSEE); Insurance Council of New Zealand (ICNZ); Property Council New Zealand (PCNZ). 
As shown in Figure 1, the stakeholders within the built environment include hazard-related professionals who provide technical information about the seismic performance of existing buildings and potential consequences in an earthquake event, so that owners can make informed mitigation decisions. A building tenant or user's choice to lease, live or use buildings in hazard-prone locations can potentially influence a property owner mitigation decision via the demand for retrofitted and nonretrofitted EPBs (Lindell, Prater 2000). The building occupier or user is relevant because they are the primary living units who are most affected by adverse consequences from an earthquake disaster. Stakeholders within the regulatory environment such as industry groups and local councils involved in natural hazard mitigation have a legal responsibility to protect the public's safety and property from earthquake hazard, by enacting legislation for seismic risk reduction and other related guidelines that may affect market perception of buildings and sale transactions. These regulations and guidelines could have significant impacts on building owners' seismic mitigation decisions (Egbelakin et al. 2013). The investment environment includes property managers, valuers and real estate agents who contribute to the moderation of business transactions of EPBs in the property market and valuation assessments. These stakeholders' activities have the potential to influence building owners' seismic retrofit and investment decisions. Similarly, stakeholders within the external environment include managers in charge of earthquake insurance policies and mortgage funds in insurance and financial organisations. These stakeholders have the capacity to influence building owners' seismic mitigation and property investment decisions, because insurance and finance availabilities ensure the business sustainability of the property market before and after a disaster event. Lastly, the building owner among these stakeholders is central to earthquake risk mitigation decision because they incur personal losses in an earthquake event, and they are responsible for making the final mitigation decision, regarding whether or not to adopt adequate mitigation measures in their EPBs. The type of mitigation decision adopted by a building owner is often a function of the type of information received from the different stakeholders.

Since the stakeholders in property investment and seismic risk mitigation decisions when an EPB is concerned are literally the same, plausibly there are significant similarities and overlaps in both decision-making processes. The stakeholders illustrated in Figure 1 operate in the different environments that could have direct or indirect impacts on building owners' earthquake mitigation decisions. The interplay between these stakeholders' operative environments play an important role that could fashion the type of mitigation measures adopted by building owners and on the overall earthquake risk and disaster management landscape. An examination of these practices may provide insights into how they directly or indirectly impact property owners' mitigation decisions.

\section{RESEARCH METHOD}

A sequential mixed-methods approach comprising both qualitative and quantitative methods was adopted in this study. In the qualitative research phase, a multiple case studies approach was adopted because this approach provide an opportunity whereby the adoption and implementation of seismic mitigation measures can be explored in terms of their relevance to the identified stakeholders. Four cities in New Zealand were selected for the case study based on their seismicity, hazard factor, percentage of non-retrofitted and retrofitted EPBs, earthquake probability and likely severity (see Table 1). Participants interviewed were selected using combined purposeful sampling that comprised snowball, key informant and referral sampling methods. This sampling method is appropriate in the context of this study, because participants were selected based on their experience and involvement in EPB projects.

Document analysis and semi-structured interviews were used as the data collection techniques. The review of essential documents, such as policy information and industry reports regarding earthquake hazard and risk mitigation, highlight the inadequacies of existing legislative provisions and risk mitigation strategies. Semistructured interviews allow the different stakeholders involved in earthquake risk management to describe the complex retrofit decision-making process, and offer insights and explanations regarding the challenges to seismic retrofit implementation. An interview protocol was developed and used as the data collection instrument for the semi-structured interviews (see Appendix Table A1). Interview participants were contacted by email and phone call to explain the nature of the research and obtain their consent to participate in the study. The primary researcher conducted 
the interviews within a period of three months. Forty-eight interviews were conducted in the selected geographic regions, which ranged from one to two hours. The interviews were audiotaped and transcribed with the interviewee's permission. Care was taken to ensure that the information provided by the participants was transcribed accurately and validated by the participants.

Content analysis was used for the analysis of the relevant documents (Yin 2009). The analysis of the relevant documents was directed at identifying the strengths and weaknesses of legislation that currently affect seismic risk mitigation plans, strategies and elsewhere programme. The interview data were analysed thematically using NVIVO qualitative data analysis software, with the objective to identify trends or themes that appeared or were repeated in the interviews. The data was coded and major themes were developed. All identified themes and subthemes were categorised separately and presented in Table 2. The findings from the qualitative phase revealed the barriers that hinder the adoption of seismic mitigation measures from the stakeholders' perspectives within the New Zealand context. These findings were subsequently used in the development of the questionnaire used in the quantitative study.

In the quantitative phase, a cross-sectional survey was used to obtain responses from a larger pool of study participants, in order to generalise research results and either to confirm or nullify some of the interview findings. Participants were randomly selected from: (1) local councils' database of approved seismic-related structural renovations approved from October 2008 to April 2012; (2) database of identified EPBs provided before and after the Canterbury earthquakes for each region; and (3) list of professionals who participated in building assessment after the 2010 and 2011 Canterbury earthquakes. Care was taken to exclude the interview participants from the survey.

The developed questionnaire was pretested in a pilot survey before an industry-wide survey was conducted. The questionnaire is available via https://www.surveymonkey.com/s/ZPGBF6V. Two hundred survey survey responses (39\% response rate) were used for the analysis, out of a total of 510 online questionnaires that were administered nationwide. Respondents were asked to indicate, on a five point Likert scale, the extent to which the identified stakeholders' practices (identified from the interview findings) could act as impediments to property owners' mitigation decisions. The Lik- ert scale is frequently used in the questionnaire, because it provides a wider choice of alternatives for the respondents (Cooper, Schindler 2013). One sample $t$-test was used to test whether the identified stakeholder's practices could significantly impede property owners' mitigation decisions (Hair et al. 2010) in SPSS software. The mean of each practice was compared. A test value of 4 was used to ascertain whether the means were significantly different. A stakeholder's practice is considered a significant impediment when $p<0.05$. The $p$-value represents the statistical significance of each stakeholder's practice. A summary of the test results is shown in Table 3. As shown in Table 3, the mean represents the average score of each stakeholder's practice. The $t$-value relate to the size of the difference between the means that is being compared. The larger the value of $t$ is, the larger the difference between the means. Only stakeholders' practices that significantly affect building owners' mitigation decisions are summarised in Table 3 and discussed in Section 3.

The survey findings verified some of the factors uncovered during the interview findings as being relevant to the influence of stakeholders' practices on risk mitigation decisions. Overall, participants selected for the study included building owners, property valuers, engineers, architects, and managers of finance, insurance and government organisations that included local councils. Building owners included people who either have or have not retrofitted their EPBs and may have or have not been affected in the recent Canterbury earthquakes, but must have been involved in retrofitted EPBs projects in the last two years. The participants were used as the main unit of analysis in both research phases.

The interview participants' and survey respondents' profiles are presented in Table 1. The analysis of the interviews and questionnaire provides general demographic information about the research participants, and suggests that most of the participants are familiar with seismic retrofitting of EPBs and the decision-making processes associated with such category buildings. Hence, they are highly experienced on the subject-matter and are in a position to provide reliable information. Likewise, the geographical distribution of the respondents indicate that a good representation of people in low-to-moderate and high-risk earthquake-prone regions in New Zealand are represented in the study. 
Table 1. Profile of research participants

\begin{tabular}{|c|c|c|c|c|c|c|c|}
\hline \multicolumn{3}{|l|}{ Survey respondents' profiles } & \multicolumn{5}{|c|}{ Interview participants' profiles } \\
\hline Category & Frequency & $\%$ & Category & Case 1 & Case 2 & Case 3 & Case 4 \\
\hline Consultants - architect & 18 & 9 & Consultants - architect & - & 1 & - & 1 \\
\hline Consultants - e.g. engineers & 56 & 28 & Consultants - engineers & 1 & 2 & 2 & 2 \\
\hline City councils officials & 24 & 12 & City councils officials & 1 & 1 & 1 & 1 \\
\hline $\begin{array}{l}\text { Managers of insurance } \\
\text { companies }\end{array}$ & 12 & 6 & $\begin{array}{l}\text { Managers of insurance } \\
\text { companies }\end{array}$ & 1 & 3 & 2 & 1 \\
\hline Property valuers & 30 & 15 & Property valuers & 2 & 3 & 2 & 1 \\
\hline Building owners & 60 & 30 & Building owners & 3 & 8 & 5 & 4 \\
\hline Respondent's location & & & Total interviewees & 8 & 18 & 12 & 10 \\
\hline Low seismic risk regions & 62 & 31 & Hazard factor $(\mathrm{z})$ & 0.13 & 0.22 & 0.36 & 0.4 \\
\hline Medium seismic risk regions & 18 & 9 & Level of earthquake risks & Low & Medium & High & Very high \\
\hline High seismic risk regions & 56 & 28 & Last significant earthquake & Oct. 2010 & Feb. 2011 & Dec. 2007 & Aug. 1942 \\
\hline Very high seismic risk regions & 64 & 32 & Percentage of EPBs (\%) & $42 \%$ & $48 \%$ & $88 \%$ & $52 \%$ \\
\hline Years of experience in EPB pr & ojects & & Retrofit standard adopted & $33 \% \mathrm{NBS}$ & $33 \% \mathrm{NBS}$ & $68 \%$ & $52 \%$ \\
\hline 5 years & 74 & 37 & Mitigation approach & Passive & Active/Passive & $52 \%$ & Active \\
\hline $6-10$ years & 46 & 23 & Population & $1,354,900$ & 390,300 & 46,600 & 389,700 \\
\hline $11-15$ years & 20 & 10 & Area $\left(\mathrm{km}^{2}\right)$ & 5,600 & 45,346 & 8,351 & 8,124 \\
\hline $16-20$ years & 12 & 6 & Sub-national GDP & $\begin{array}{l}\text { US } \$ 28,250 \\
\text { billion }\end{array}$ & $\begin{array}{l}\text { US } \$ 15,08 \\
\text { million }\end{array}$ & $\begin{array}{l}\text { US } \$ 66.3 \\
\text { million }\end{array}$ & $\begin{array}{l}\text { US } \$ 142.5 \\
\text { million }\end{array}$ \\
\hline $21-25$ years & 22 & 11 & & & & & \\
\hline$>25$ years & 26 & 13 & & & & & \\
\hline
\end{tabular}

Notes:

- Hazard factor (z) - The equivalent to an acceleration coefficient with an annual probability of exceedance in 1/500) for different locations in New Zealand.

- Seismicity - used to establish the probability and severity of a seismic event, which varies between provinces.

- Sub-national GDP.

- EPBs are determined using the performance achievement ratio (PAR); a measure of an individual building's expected performance in an earthquake event, independent of location and which primarily takes into consideration the critical structural weakness such as plan, vertical irregularity and pounding potential.

Table 2. Interview findings - stakeholders' practices affecting earthquake mitigation decisions

\begin{tabular}{|c|c|c|c|}
\hline \multirow{2}{*}{$\begin{array}{l}\text { Environ- } \\
\text { ments }\end{array}$} & \multirow[t]{2}{*}{ Stakeholders } & \multicolumn{2}{|c|}{ Stakeholders' practices } \\
\hline & & Main themes & Subthemes \\
\hline \multirow[t]{2}{*}{$\begin{array}{l}\text { Invest- } \\
\text { ment envi- } \\
\text { ronment }\end{array}$} & \multirow[t]{2}{*}{$\begin{array}{l}\text { Property managers } \\
\text { and valuers, potential } \\
\text { investors and real estate } \\
\text { agents }\end{array}$} & $\begin{array}{l}\text { Property valuation } \\
\text { assessment }\end{array}$ & $\begin{array}{l}\text { Valuation and property standards not directly addressing issues } \\
\text { relating to seismic risks } \\
\text { Lack of perceived financial benefits from adopting seismic mitigations } \\
\text { Estimated historic value of heritage buildings }\end{array}$ \\
\hline & & $\begin{array}{l}\text { Property } \\
\text { acquisition }\end{array}$ & $\begin{array}{l}\text { Lack of awareness of seismic risk issues among players } \\
\text { Lack of demand for improved performance of older buildings }\end{array}$ \\
\hline $\begin{array}{l}\text { Built } \\
\text { environ- } \\
\text { ment }\end{array}$ & $\begin{array}{l}\text { Professionals (architects } \\
\text { and engineers), users } \\
\text { (tenants, customers and } \\
\text { employees) }\end{array}$ & $\begin{array}{l}\text { Technological } \\
\text { advances for } \\
\text { earthquake miti- } \\
\text { gation }\end{array}$ & $\begin{array}{l}\text { Lack of a unified information system regarding an individual build- } \\
\text { ing's seismic risk properties } \\
\text { Lack of knowledge regarding seismic risk issues } \\
\text { Elsewhere programme for property owners } \\
\text { Non-availability of cost-effective and sustainable retrofit design and } \\
\text { innovations } \\
\text { Improve economic sustainability of EPBs }\end{array}$ \\
\hline $\begin{array}{l}\text { Regulatory } \\
\text { environ- } \\
\text { ment }\end{array}$ & $\begin{array}{l}\text { City or territorial, coun- } \\
\text { cils, Department of Build- } \\
\text { ing and Housing (DBH), } \\
\text { New Zealand Society for } \\
\text { Earthquake Engineers } \\
\text { (NZSEE) }\end{array}$ & $\begin{array}{l}\text { Regulatory } \\
\text { provisions }\end{array}$ & $\begin{array}{l}\text { Weak implementation of the earthquake risk mitigation policy } \\
\text { Lack of mandatory seismic risk disclosure in property market trans- } \\
\text { actions } \\
\text { Monetary fines or sanctions for owners of high earthquake risk } \\
\text { buildings }\end{array}$ \\
\hline \multirow[t]{2}{*}{$\begin{array}{l}\text { External } \\
\text { environ- } \\
\text { ment }\end{array}$} & \multirow[t]{2}{*}{$\begin{array}{l}\text { Insurance and financial } \\
\text { institutions }\end{array}$} & $\begin{array}{l}\text { Earthquake } \\
\text { insurance policy } \\
\text { provisions }\end{array}$ & $\begin{array}{l}\text { Insurance premiums not reflecting building seismic risks } \\
\text { Lack of a risk-based insurance premium scale } \\
\text { High insurance premium and deductible } \\
\text { Insurance as a only risk management strategy }\end{array}$ \\
\hline & & $\begin{array}{l}\text { Financing EPBs } \\
\text { retrofit projects }\end{array}$ & $\begin{array}{l}\text { Difficulty in securing finance loans to retrofit EPBs } \\
\text { High loan interest rates }\end{array}$ \\
\hline
\end{tabular}




\section{STAKEHOLDERS' PRACTICES IMPEDING EARTHQUAKE RISK MITIGATION DECISIONS}

Stakeholders involved in building seismic retrofit and investment decisions were examined within their operative environments to understand how their practices affect building owners' mitigation decisions. Only significant stakeholders' practices acting as impediments to building owners' mitigation decisions are discussed from the operational perspective of the stakeholders' environments.

\subsection{Investment environment}

Three stakeholders' practices identified within the investment environment acting as impediments to owners' mitigation decisions are: property valuation assessments, lack of perceived financial benefit and lack of demand for retrofitted older buildings (see Table 3).

\subsubsection{Property valuation assessments of retrofitted and non-retrofitted EPBs}

A pertinent issue identified in this environment involves property valuation assessments of retrofitted and non-retrofitted EPBs. The interview analysis revealed that earthquake risk receives a marginal consideration in the assessment of property values and current investment practices in New Zealand. Given that earthquake risk appears to have a potentially significant effect on the overall income return from properties, and on their market value at the time of an earthquake event (Onder et al. 2004), seismic risk is poorly accounted for in property valuation and investment decisions. Sixty-eight percent of the property valuers interviewed explained that seismic risks are usually not considered in property valuation reports unless specifically requested by their clients. There is a general assumption among stakeholders in the property market that risks associated with earthquakes are covered by insurance. One of the stakeholders interviewed opined that:

"Most times when making real estate investment decisions, we assume that risks from rare disaster events such as earthquake are negligible compared to other market risks relating to the building's net operating income and taxation".

This statement and several other assertions from the interviews suggest that seismic risks are not generally considered in the financial analysis of most investment opportunities, because earthquake risks are not considered significant in property valuation assessment. As a result, there is insufficient weighting attached to potential earthquake strengthening costs in investment and purchase decisions. For example, findings after the Canterbury earthquake reveal that the owner of the CTV (Canterbury Television) building was unaware of the building's seismic risks at the time of purchase (Egbelakin et al. 2013). There is a possibility that if the present CTV building owner had been made aware of the extent of the building's vulnerability to earthquake risks, the cost of retrofitting could have been factored into the investment decision and retrofitting work possibly undertaken. Findings from the interviews revealed that earthquake risk assessment exclusion from property valuation practice was attributed to the Australia and New Zealand Valuation and Property Standards. The standards do not directly address issues relating to seismic risks. The onus is left to the valuer's discretion. The general practice among valuers is to include a disclaimer on any related seismic risks in their valuation report to reduce the scope and rights that may be exercised,

Table 3. Survey results - significant stakeholders practices acting as impediments to earthquake mitigation decisions

\begin{tabular}{|c|c|c|c|c|c|}
\hline \multirow[t]{2}{*}{ Environments } & \multicolumn{2}{|l|}{ Stakeholders' practices } & \multicolumn{3}{|c|}{ Test value $=4$} \\
\hline & Main themes & Subthemes & Mean & t-value & $\mathrm{p}$-value \\
\hline \multirow[t]{3}{*}{$\begin{array}{l}\text { Investment } \\
\text { environment }\end{array}$} & \multirow[t]{2}{*}{$\begin{array}{l}\text { Property valuation as- } \\
\text { sessments }\end{array}$} & $\begin{array}{l}\text { Valuation and property standards not ad- } \\
\text { dressing issues relating to seismic risks }\end{array}$ & 6.38 & 4.68 & 0.001 \\
\hline & & $\begin{array}{l}\text { Lack of perceived financial benefits from } \\
\text { adopting seismic mitigations }\end{array}$ & 5.86 & 4.29 & 0.001 \\
\hline & Property acquisition & $\begin{array}{l}\text { Lack of demand for improved performance of } \\
\text { older buildings }\end{array}$ & 5.88 & 3.36 & 0.002 \\
\hline $\begin{array}{l}\text { Regulatory } \\
\text { environment }\end{array}$ & Regulatory provisions & $\begin{array}{l}\text { Lack of mandatory disclosure of seismic risk } \\
\text { information }\end{array}$ & 6.48 & 5.21 & 0.000 \\
\hline \multirow[t]{2}{*}{ Built environment } & \multirow[t]{2}{*}{$\begin{array}{l}\text { Information flow and } \\
\text { dissemination system }\end{array}$} & $\begin{array}{l}\text { Lack of knowledge regarding seismic risk is- } \\
\text { sues in the property market }\end{array}$ & 5.89 & 4.33 & 0.005 \\
\hline & & Lack of knowledge about seismic risk issues & 4.28 & 3.88 & 0.003 \\
\hline \multirow{2}{*}{$\begin{array}{l}\text { External } \\
\text { environment }\end{array}$} & \multirow{2}{*}{$\begin{array}{l}\text { Earthquake insurance } \\
\text { policy provisions }\end{array}$} & High insurance premium and deductible & 5.46 & 5.21 & 0.001 \\
\hline & & Lack of a risk-based insurance premium scale & 6.32 & 5.61 & 0.000 \\
\hline
\end{tabular}


should a case of litigation ensue. Even in cases where earthquake risk is included in investment decisions specifically, in regions susceptible to high seismic risks, such as in Cases 3 and 4, there is currently no consensus on how to adequately embed the analysis of seismic retrofit cost-effectively into a property valuation assessment. Statistical results from the survey data show that excluding seismic risks from valuation assessments can significantly impede building owners' mitigation decisions $(t=4.68$ and $p=0.001)$.

\subsubsection{Lack of perceived financial benefits}

The lack of perceived financial benefits from seismically retrofitting EPBs in the short term was found to be a constraint to risk mitigation decisions. The majority of owners interviewed across all cases complained that seismic retrofitting costs are enormous. This group of participants are of the opinion that it is difficult to recapture money expended on seismic retrofitting of EPBs from increased property value or income stream. In the words of one of the private owners:

"Most of us who own EPBs find it difficult to recover the cost expended to seismically retrofit these buildings because the cost of retrofitting does not increase the property value or rents from the building".

This statement suggests that a low level of perceived seismic retrofit benefits, either at the time of property sale or during a lease, explains why some owners are reluctant to adopt mitigation measures. Ninety-two percent of the building owners interviewed agreed that they would likely strengthen their EPBs, if the initial cost of implementation could be recovered through increased property rent or value. However, increasing the income stream or property value of a retrofitted EPB correlates to an occupier's or purchaser's willingness to pay for a premium for the improved safety. However, $86 \%$ of property valuers argue that differentiating the income-producing capacity of buildings that have been retrofitted from those that have not been retrofitted may be difficult, as the occupiers are likely to pay the same rents for both building types (provided they are similar in terms of rental space and location). Anecdotal evidence suggests most occupiers are not willing to pay any premium for improved safety in EPBs via increased rents. Hence, the lack of perceived benefits from retrofitting acts as an impediment to seismic retrofitting of EPBs. Statistical analysis supports this interview finding that lack of perceived benefits from retrofitting EPBs poses a significant barrier to improving the seismic capacity of existing EPBs in New Zealand $(t=5.29$ and $p=0.000)$.

\subsubsection{Lack of demand for improved performance of older buildings}

Another issue identified as an obstacle to seismic rehabilitation of EPBs in New Zealand is the lack of demand for improved performance of older buildings. Anecdotal evidence from the interviews suggest that there is a gradual decrease in the demand for older buildings, as market preferences now tend towards newer buildings, where energy efficiency and sustainability can be optimally achieved. Most of the older buildings within the four city centres and suburbs covered by this study were found to have some of the upper floor(s) unoccupied due to lack of demand. The majority of the building owners interviewed explained that seismic retrofitting of EPBs could lead to loss of revenue, poor aesthetics and impaired functional utility. Also the participants said that there is the likelihood that useable or rentable floor area may be lost during retrofitting. These constraints often discourage the implementation of mitigation measures. The interviewees suggested that a way to increase the demand for many older EPBs would be to seismically rehabilitate the buildings and ensure that they achieve lower operating costs for the users. Hence improving the building's sustainability or obtaining higher occupancy rates and overcoming market concerns regarding health and safety issues may serve as a motivator for retrofitting. Findings from this study, presented in Table 3, provide empirical justification that lack of demand for seismically strengthened older buildings impedes property owners' mitigation decisions $(t=3.36$ and $p=0.002)$.

\subsection{Regulatory environment}

A pertinent impediment to mitigation decisions arising from the regulatory environment relates to the lack of mandatory disclosure of seismic risk information as shown in Table 3.

\section{Non-mandatory disclosure of seismic risk information}

Non-mandatory disclosure limits awareness and knowledge on issues related to seismic risk and the adoption of mitigation measures in EPBs, which can lead to underinvestment in earthquake risk mitigation by owners. Currently, none of the regulatory mechanisms relevant to earthquake risk mitigation in New Zealand specifically address whether or not disclosure of building seis- 
mic risks should be mandatory. Hence, there is no incentive for seismic risk disclosure at the point of sale or lease of a building in the property market. One of the participants disclosed that:

"It is difficult for all market stakeholders to know the issues around seismic risks unless the law mandates that it must be disclosed. Most owners and real estate agents will prefer to be silent on such issues because it will affect their business transactions".

Across all cases covered by the current study, $63 \%$ of the participants believed that disclosing a property's seismic risk at the point of sale or lease would warn people about the property's risk, improve seismic risk awareness in the market, and consequently enhance the adoption of seismic mitigations. In the words of a participant:

"Mandatory disclosure of seismic risks will increase risk awareness in the market and possibly could force down the value of non-retrofitted EPBs".

However, some of the building owners and real estate agents claim that mandatory disclosure of a building's seismic risks would slow down the time taken to complete sale or rental transactions. Mandatory disclosure could also cause immediate strengthening of many EPBs, which could cause strong inflationary pressures if a large number of property owners upgrade at the same time. From data presented in Table 3, it is observed that a lack of mandatory seismic risk disclosure information by relevant regulatory mechanisms serves as an impediment to risk mitigation decisions $(t=5.51$ and $p=0.000)$.

\subsection{Built environment}

The built environment has been of much focus and discussion in relation to seismic retrofit decisions regarding EPBs. Pertinent issues identified within the built environment relate to the lack of unified information dissemination systems and lack of knowledge regarding seismic risk issues.

\subsubsection{Lack of a unified seismic risk information system}

A lack of unified information system to readily disseminate information regarding individual buildings' seismic properties impedes other stakeholders from making appropriate decisions regarding the assessment of a building's seismic risks and potential mitigation measures. Although there is significant knowledge about earthquake event and its potential impact on the built environment, many of the stakeholders do not have access to this information and knowledge. The interviews reveal a consensus across all the participants in the four regions investigated, that the lack of an information system regarding an individual building's seismic properties would consequently affect owners' retrofit decisions. One property valuer said:

'We do not have access to many buildings' seismic risk properties making our job as valuers difficult. The lack of this information has contributed to the lack of awareness regarding earthquake risk in the market. A generally acceptable risk in the market will increase the need to include seismic risk in valuation analysis because owners, investors and insurers will ask for it".

Lack of information could mislead the market stakeholders regarding issues surrounding vulnerability of properties to seismic risks, consequently leading to underestimation of risk mitigation costs in investment decisions. Across all participants, there was general consensus that the lack of a unified information dissemination system impedes risk mitigation decisions in New Zealand $(t=4.33$ and $p=0.005)$.

According to the research findings, easily accessible information about a building's seismic capacity is relevant and could enhance other stakeholders' practices in the property market. For instance, insurance brokers and property valuers need access to information about a building's seismic risk in order to determine the likely risk premium and appropriate property value.

\subsubsection{Lack of knowledge about seismic risk issues}

The qualitative study investigation revealed that most of the stakeholders in the property market have little or no knowledge about EPBs, seismic performance standards, legal obligations and potential liabilities relating to changes in the Building Act 2004 (Department of Building and Housing 2004) earthquake requirements and local governments EPBs policies. Seventy-nine percent of participants in Case 1 were unaware of the recent changes made to seismic risk mitigation obligations imposed by the Building Act. This lack of awareness reported in Case 1 can also be attributed to the low seismicity and lack of any significant earthquake event in the region. However in Cases 2 and 3 , there is an increasing trend in the level of awareness of seismic risk-related issues among market stakeholders due to the impacts of the recent disastrous earthquake events in the regions.

Insights from the interviews suggest that the lack of seismic risk awareness and knowledge within the market can be linked to property 
vendors' and real estate agents' disregard of issues relating to EPBs and current strengthening levels, so that property sale or rent transaction period is not reduced. Sixty-seven percent of the owners interviewed claim that they do not understand how the degree of strengthening implemented earlier in a building is comparable to a new building at the time of purchase of their buildings. Most buildings that have been 'strengthened' in the past have had this done to comparatively low levels compared with the current code requirements. Further, the interview findings reveal that many tenants or owners have purchased or leased buildings with the belief that they have been 'strengthened' or even 'fully strengthened to $100 \%$ of the current regulations'. These owners and tenants are unaware that the code being referred to is the 1965 version. As a result, the degree of strengthening is substantially less than that of comparable new buildings under the newly revised building regulations (Department of Building and Housing 2005).

Lack of knowledge of seismic risk mitigation issues and legislation about seismic risk issues in the property market thus undermines the promotion of earthquake hazard mitigation $(t=3.88$ and $p=0.003)$.

\subsection{External environment}

Insurance is a major component in the overall risk management strategy for a building, and using this as a risk management strategy has significant implications for earthquake mitigation (Spence, Coburn 2006). The lack of a risk-based insurance premium assessment, high insurance deductibles and premiums were identified as impediments to building owners adopting adequate mitigation measures (see Table 3).

\subsubsection{High insurance premiums and deductibles}

Generally, the cost of earthquake insurance and the policy deductibles is relatively high in New Zealand, when compared to other seismically active countries. The qualitative findings indicate that earthquake insurance premiums and policy deductibles are viewed by many property owners as too costly, which often reduces their willingness to purchase an insurance policy. Eighty-six percent of the participants in Case 2 mentioned that owners of EPBs often find it difficult to obtain earthquake insurance and in most cases pay high insurance premiums and are being subjected to higher deductibles. One of the building owners stated that:

"It was difficult for me to get insurance for this building and I have to pay a huge amount of money in insurance premiums. Moreover, the deductibles are really high. How can I source for such an amount of money if an earthquake does occur?"

High premiums further increase building operating costs, thus becoming an obstacle to a seismic mitigation decision. The recent significant earthquake in February 2011 has demonstrated the economic implication of disasters, thus contributing to the increase in insurance premiums and deductibles. Generally, among the participants the high earthquake insurance premiums and deductibles in New Zealand were attributed to the country's high seismicity, recent devastating earthquake and short-term insurance policy programme. Insights from the interviews suggested that properties in seismically active zones usually carry higher deductibles and premium rates than those in regions that are less seismically active. Participants from the insurance industry occupying senior management positions argued that the market usually reacts to risk and uncertainty by increasing investment risk premiums as evidenced by the impacts of the recent earthquake events in New Zealand. Statistical results from the survey data show that high insurance premiums and deductibles significantly impede decisions regarding seismic retrofitting of EPBs $(t=5.21$ and $p=0.001)$.

\subsubsection{Lack of a risk-based insurance premium}

The lack of a risk-based insurance premium assessment and high loan interest rates were identified as some of the factors that affect building owners' mitigation decisions. A participant stated:

"The insurance broker told me even if I retrofit my building to higher performance level, the insurance premium and deductible is not likely to change, so why retrofit my building".

Also, evidence from the findings showed that the cost of insurance premiums does not reflect seismic mitigation actions implemented in a retrofitted EPB. Eighty-two percent of the participants explained that generally the insurance premium is not calculated in terms of risk-based analysis and complained about the lack of a risk-based premium scale. Forty-eight percent of the owners interviewed who have retrofitted some of their EPBs to a structural performance standard greater than $67 \%$ of New Building Standard (NBS) complained that they were unable to secure a policy that re- 
flects the level of risks posed by their retrofitted EPBs. Insights from the interviews suggested that insurance premiums should reflect risk and take into account mitigation actions on the building, provided the potential insurance losses on the structure are reduced by implementing such actions. This is yet to be the case in New Zealand. Participants from the insurance industry claimed that accessing individual seismic mitigation actions on EPBs is difficult and costly because each building is different, requiring separate assessments. Moreover, the lack of a reliable database for information regarding the seismic risk characteristics of these buildings hampers the assessment of the mitigation actions undertaken. Ninety-two percent of the interviewees suggested that buildings retrofitted well beyond minimum requirement should be eligible for premium discounts, indicating that a reduction in insurance premiums is a key component of any hazard mitigation programme aimed at improving seismic retrofit decisions. However, insurers are unwilling to offer a discount because a reduction in insurance premiums is likely to attract more owners of EPBs which increases an insurance company's risk exposure in the event of an earthquake. Statistically, the survey findings showed that the lack of a risk-based insurance premium assessment significantly impedes mitigation decisions $(t=5.61$ and $p=0.000)$.

\section{DISCUSSION OF FINDINGS}

The property market as a whole has gained considerable attention in moderating the market value of a building, but little emphasis has been placed on understanding its full impact on seismic retrofit decisions. The research findings provide insights as to why earthquake risk reduction measures are not adequately implemented in New Zealand across low to moderate and high seismic risk regions. Figure 2 depicts an improvement on Figure 1 to reflect information obtained from the survey results reported in the previous section. Figure 2 represents a framework that provides insights about the causal agents (stakeholders) and significant pathways (practices within operative environments) that pose challenges to seismic retrofit implementation, as well as a means of enhancing property owners' decisions. Although this framework is not a complete explanation of the impact of stakeholders' practices on mitigation decisions, it

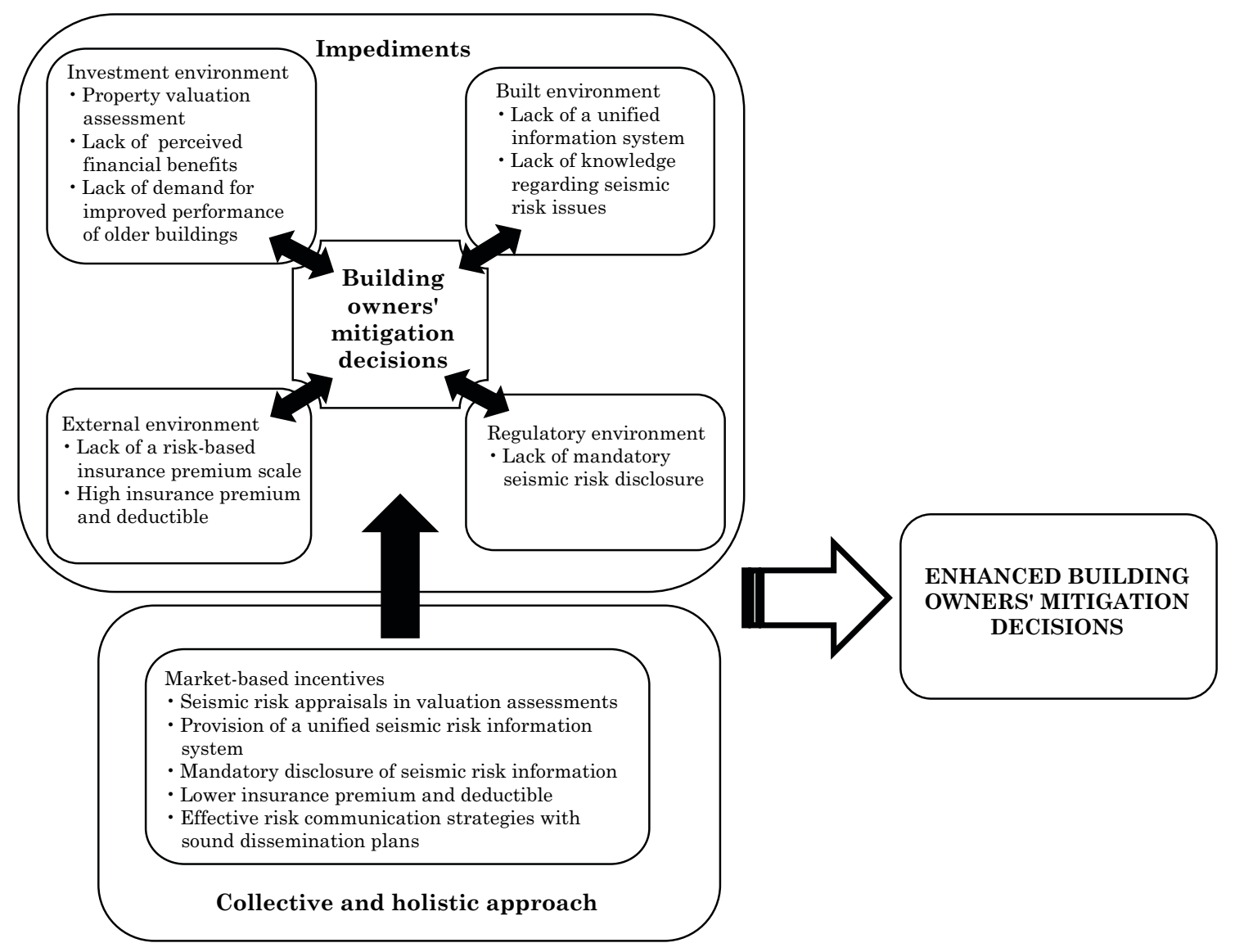

Fig. 2. Framework for enhancing seismic risk mitigation decisions 
is a first attempt at constructing some hypotheses that may be tested empirically in future research.

In addition, several market-based incentives were suggested via the research findings and deductive reasoning as potential strategies to improve current stakeholders' practices, and for promoting the adoption of adequate risk mitigation measures in EPBs. The market-based incentives suggested include seismic risk appraisals in property valuation assessments, provision of a unified seismic risk information system, mandatory disclosure of seismic risk information in property market transactions, accuracy in earthquake risk assessment methods and the use of a risk-based insurance premium system.

The research results appear to confirm that mandatory disclosure of seismic risk in earthquake policies would provide accurate information to the buyer, insurer and lending institution. All parties involved in the property market transaction would understand the risks inherent in the building before completing a transaction. For instance, property traders would become aware that property value would be reduced if the building seismic risks are disclosed, while the insurer would be able to adequately estimate the building risks through a risk-based premium. Mandatory disclosure of a building's seismic risks in all transactions would increase the salience of seismic risk issues, enhance the likelihood of property owners adopting adequate risk mitigation measures, and consequently lead to improved earthquake risk mitigation in existing EPBs.

The availability of a unified seismic risk information system would help other relevant professional groups and property market stakeholders to access any building's risk data. This data would help them become aware of commonly encountered issues and imperatives regarding earthquake risks. Property valuers can adequately estimate the extent of mitigation costs for any retrofitted buildings in property valuation assessment reports, thus influencing the price-setting and valuation process of individual property transactions. Likewise, an insurer would adequately estimate the building's seismic risk through a risk-based premium, reducing the capitalisation rates of retrofitted buildings due to lower investment risks and premiums. Lower insurance premiums for retrofitted EPBs would assure building owners of reduced operational costs, thus serving as an incentive to retrofit EPBs. Finally, all stakeholders involved in earthquake risk mitigation would be adequately informed about the earthquake risks, costs and benefits of retrofitting EPBs, lead- ing to an informed market. Accuracy in earthquake risks assessments is closely related to the methods of identifying strategies for mitigation. Improved risk assessment would enhance both appropriate risk estimation and adoption of adequate mitigation measures in retrofitted EPBs, would help insurers to accurately set premiums, and tailor their portfolio to reduce the chances of insolvency, and would reduce information irregularities between insurers, reinsurers and financial institutions

The implementation of the market-based incentives identified in this paper, although they operate independently, requires a collective and holistic approach, in order to achieve the wider disaster mitigation objectives. The research findings thus highlight the need for collective adaptive utility among the stakeholders involved in the property market and earthquake disaster management (see Fig. 2). It can be therefore inferred that when stakeholders, such as insurers and regulatory institutions, who regulate transactions in the property market, adopt practices aimed at improving earthquake risk mitigation, it could result in a type of leverage that attempts to regulate the choices of other stakeholders such as building owners with regards to mitigation options.

\section{CONCLUSION}

The importance of seismic retrofit implementation is reflected by a growing number of buildings that are abandoned to decay or be demolished within the built environment. Promoting the adoption of earthquake risk mitigation measures in EPBs is essential for reducing fatalities, damage to property and infrastructure, as well as economic and social disruption in a seismic disaster. This study examined how building owners' mitigation decisions are influenced by property market stakeholders' practices. It examines the different stakeholders involved in property investment and seismic retrofit implementation within their respective operational environments. The stakeholders' practices that could become impediments to effective mitigation decision-making include property valuation assessments, lack of demand for retrofitted older buildings, lack of mandatory disclosure of risk information, high earthquake insurance deductibles and lack of a unified risk information system. These factors were determined through a mixed-methods study approach. Further, several market-based incentives were suggested as potential strategies to improve current stakeholders' practices, and for enhancing property owners' mitigation decisions. 
These incentives include mandatory disclosure of property seismic risks during market transactions, provision of a unified risk information system and adequate assessment of seismic risks in property valuation. These incentives could act as motivators and/or persuasive reasons for different stakeholders and the public at large to retain, care, invest, and act responsibly in the rehabilitation of EPBs. There is a probability that if adequate strategies involving some of these incentives were developed or nurtured, the market place might eventually assist in rehabilitating many EPBs within the community.

Findings from this research are beneficial to both researchers and professionals involved in the seismic rehabilitation of EPBs. The results of this current study add to the growing body of literature examining the impacts of natural hazard and disaster on the built environment. Most importantly, the research findings reported in this study should be seen as an initial effort to understand how the property market forces and its stakeholders' practices affect seismic rehabilitation of EPBs. There is a need for further empirical analysis of retrofitting actions adopted, following the dissemination of this research report in order to determine the adequacy of these incentives in actual promotion of earthquake risk mitigation. Further research is necessary to examine the relative impacts of these incentives on property market transactions and earthquake risk mitigation. Overall, it is important to note that the research results concern various stakeholders involved in seismic retrofitting and property investment decisions. Plausibly, earthquake risk mitigation plans that fail to recognise the interrelationships among these stakeholders and their operating environments may be deficient, leading to sub-optimal outcomes. The study goes further to suggest improved collaboration among these stakeholders is necessary to foster successful seismic rehabilitation of EPBs.

\section{ACKNOWLEDGEMENT}

This research is part of the collaborative project on implementing seismic retrofit solutions between the Universities of Auckland and Canterbury University, New Zealand. The authors gratefully acknowledge the support from the New Zealand Foundation for Research (FSRT). This publication reflects the views only of the authors, and the FRST cannot be held responsible for any use which may be made of the information contained therein.

\section{REFERENCES}

Adair, A.; Berry, J.; McGreal, S. W. 1994. Investment decision making: a behavioural perspective, Journal of Property Finance 5(4): 32-42. http://dx.doi. org/10.1108/09588689410080275

Arlikatti, S.; Lindell, M. K.; Prater, C. S.; Johnston, D. 2007. Perceived stakeholder role relationships and adoption of seismic hazard adjustments, International Journal of Mass Emergencies and Disasters 25(3): 218-256.

Beck, J.; Porter, K.; Shaikhutdinov, R.; Au, S.; Mizukoshi, K.; Miyamura, M.; Ishida, H.; Moroi, T.; Tsukada, Y.; Masuda, M. 2002. Impact of seismic risk on lifetime property values. California Institute of Technology.

Bostrom, A.; Turaga, R.; Ponomariov, B. 2006. Earthquake mitigation decisions and consequences, Earthquake Spectra 22(2): 313-327. http://dx.doi. org/10.1193/1.2190668

Burton, I.; Huq, S.; Lim, B.; Pilifosova, O.; Schipper, E. L. 2002. From impacts assessment to adaptation priorities: the shaping of adaptation policy, $\mathrm{Cli}$ mate Policy 2(2): 145-159. http://dx.doi.org/10.3763/ cpol.2002.0217

Cooper, D.; Schindler, P. 2013. Business research methods. McGraw-Hill Education.

Department of Building and Housing. 2004. The Building Act. Wellington: Brookers Ltd.

Department of Building and Housing. 2005. Earthquakeprone buildings provisions of the Building Act 2004: policy guidance for territorial authorities. Wellington: Brookers Ltd.

Dowrick, D. J. 2003. Earthquake risks reduction actions for New Zealand, Bulletin of the New Zealand Society for Earthquake Engineering (NZSEE) 36(4): 249-259.

Earthquake Engineering Research Institute. 1998. Incentives and impediments to improving the seismic performance of buildings. California: EERI Publications.

Egbelakin, T. 2013. Earthquake risks mitigation - a stakeholder's perspective. Singapore: Lambert Academic Publishing.

Egbelakin, T.; Wilkinson, S. 2008. Factors affecting motivation for improved seismic retrofit implementation, in Australian Earthquake Engineering (AEES) conference, 21-23 November 2008, Ballarat, Victoria, Australia, 26-36.

Egbelakin, T.; Wilkinson, S. 2010. Sociological and behavioural impediments to earthquake hazard mitigation, International Journal of Disaster Resilience in the Built Environment 1(3): 310-321. http://dx.doi. org/10.1108/17595901011080896

Egbelakin, T.; Wilkinson, S.; Potangaroa, R.; Ingham, J. 2011a. Enhancing seismic risk mitigation decisions: a motivational approach, Construction Management and Economics 29(10): 1003-1016. http://dx.doi.org/ 10.1080/01446193.2011.629664

Egbelakin, T.; Wilkinson, S.; Potangaroa, R.; Ingham, J. M. 2011b. Challenges to successful seismic retrofit implementation: a socio-behavioural perspective, 
Building Research \& Information 39(3): 286-300. http://dx.doi.org/10.1080/09613218.2011.552264

Egbelakin, T.; Wilkinson, S.; Potangaroa, R.; Ingham, J. 2013. Improving regulatory frameworks for earthquake risk mitigation, Building Research \& Information 41(6): 677-689. http://dx.doi.org/10.1080/096132 18.2013.819546

Hair, J. F.; Black, B. C.; Babin, B. J.; Anderson, R. E. 2010. Multivariate data analysis: a global perspective. London: Pearson Education.

Hopkins, D.; Sharpe, R.; Sucuoğlu, H.; Kubin, D. 2006. Residential retrofitting in Istanbul: key issues to make implementation possible, in $8^{\text {th }}$ U.S. National Conference: Earthquake Engineering, 18-22 April 2006, San Francisco, California.

Lindell, K. M.; Prater, C. S. 2000. Household adoption of seismic hazard adjustments: a comparison of residents in two states, International Journal of Mass Emergencies and Disasters 18(2): 317-338.

McElroy, B.; Mills, C. 2008. Managing stakeholders, in R. J. Turner, S. J. Simister (Eds.). Gower handbook of project management. $3^{\text {rd }}$ ed. Aldershot: Gower Publishing Limited, 757-775.

Onder, Z.; Dokmeci, V.; Keskin, B. 2004. The impact of public perception of earthquake risk on Istanbul's housing market, Journal of Real Estate Literature 12(2): 181-196.

Pidgeon, N. F.; Kasperson, R. E.; Slovic, P. 2003. The social amplification of risk. Cambridge: Cambridge University Press. http://dx.doi.org/10.1017/ CB09780511550461

Slovic, P. 2001. The perception of risk. London: Earthscan.
Smith, K. 2009. Environmental hazards: assessing risk and reducing disaster. London: Routledge.

Solberg, C.; Rossetto, T.; Joffe, H.; Gayer, G.; Leschka, S.; Nöhren, I.; Larsen, O.; Günther, H. 2010. The social psychology of seismic hazard adjustment: reevaluating the international literature, Natural Hazards and Earth System Sciences 10(8): 1663-1677. http://dx.doi.org/10.5194/nhess-10-1663-2010

Spence, R. 2007. Saving lives in earthquakes: successes and failures in seismic protection since 1960, Bulletin of Earthquake Engineering 5(2): 139-251. http:// dx.doi.org/10.1007/s10518-006-9028-8

Spence, R.; Coburn, A. 2006. Earthquake risk and insurance, in K. Atilla Ansal (Ed.). Assessing and managing earthquake risk, Dordrecht: Springer, 385-402.

Stevens, C. M.; Wheeler, K. E. 2008. Implementing earthquake prone building policy under the Building Act 2004 - Wellington City's approach, in Proceedings of New Zealand Society for Earthquake Engineering: Engineering an Earthquake Resilient New Zealand (NZSEE) conference, 11-13 April 2008, Wairakei, New Zealand.

Tierney, K.; Khazai, B.; Tobin, L.; Krimgold, F. 2005. Social and public policy issues following the 2003 Bam, Iran, Earthquake, Earthquake Spectra 21(S1): S513-S534. http://dx.doi.org/10.1193/1.2098928

Willis, K.; Asgary, A. 1997. The impact of earthquake risk on housing markets: evidence from Tehran real estate agents, Journal of Housing Research 8: 125136.

Yin, R. K. 2009. Case study research: design and methods. Los Angeles: Sage Publications.

\section{APPENDIX}

Table A1. Interview protocol by research questions

\begin{tabular}{ll}
\hline Research question & Discussion areas or probes \\
\hline What are the challenges that & Policy implementation processes and requirements \\
you encountered when you were & Stakeholders' involvement \\
involved in any seismic retrofit & Interaction with related council officers \\
project? & Property valuation assessments \\
& Demand for improved performance of older EPBs \\
& Awareness and knowledge regarding seismic risk issues \\
& Earthquake risk information and communication \\
Given the nature of your busi- & Structural design solutions (cost implications and perceived effectiveness) \\
ness/profession, can you describe & Seismic retrofit standards \\
the strategies that you use in re- & Regulatory provisions and compliance to earthquake policy and regulations \\
ducing earthquake risks? & Insurance \\
& Property market conditions \\
& Motive of implementing mitigation \\
& Technological advances for earthquake mitigation \\
Can you describe the benefits and & Personal attributes such as beliefs and values \\
values you associate with retrofit- & Protecting family and property \\
ting EPBs? & Business or work interference \\
& Heritage conservation \\
& Financial gains \\
\hline
\end{tabular}

